\title{
A Single Center Experience in Biological Therapy for the Treatment of Rheumatoid Arthritis in Saudi Arabia
}

\author{
Sultana Abdulaziz ${ }^{1 *}$, Basem El-Deek ${ }^{2}$ \\ ${ }^{1}$ Department of Medicine, King Fahad Hospital, Jeddah, KSA \\ ${ }^{2}$ King Abdulaziz University, Jeddah, KSA \\ Email: drsabdulaziz@yahoo.com
}

Received 5 August 2014; revised 5 September 2014; accepted 5 October 2014

Copyright (C) 2014 by authors and Scientific Research Publishing Inc.

This work is licensed under the Creative Commons Attribution International License (CC BY). http://creativecommons.org/licenses/by/4.0/

(c) (i) Open Access

\section{Abstract}

Background: Biological therapy is indicated in the treatment of RA (Rheumatoid Arthritis) after failure of disease-modifying anti-rheumatic drugs (DMARDS) by the ACR/EULAR recommendations. The objective of the study is to describe the characteristics of Saudi patients at the initiation of biological therapy and to evaluate clinical effectiveness of this therapy measured by the disease activity score DAS 28. Methods: This was a retrospective cohort study of RA (rheumatoid arthritis) patients in King Fahad Hospital in Jeddah, Saudi Arabia from January 2005-July 2011. Data were collected from the medical records of all RA patients on biological therapy including: demographics, disease characteristics, comorbid illnesses and DAS 28 score over a period of 1 year. Results: 139 patients were studied (mean age $46 \pm 13$ years), of which 118 (84\%) were females; mean duration of affliction with $R A$ was 7.2 years ranging 1 - 45 years. Rheumatoid factor (RF) was positive in 88 patients (63.3\%) and one or more comorbidities were present in 102 patients $(73.3 \%)$. First choice of biological drug was ADA (Adalimumab) 44 patients (31.7\%) and RTX (Rituximab) was the $2^{\text {nd }}$ frequently prescribed biological drug. Mean DAS 28 activity at baseline was in ADA 41 patients $(6.10 \pm 1.62)$, ETA (Etarnercept) 29 patients $(6.64 \pm 1.42)$ and RTX 50 patients $(6.7 \pm 1.32)$. Moderate to good EULAR response was obtained in $74 \%, 85.7 \%$ and $53.3 \%$ at 6 months in ADA, ETA and RTX patients respectively. Moderate to good EULAR response was obtained in $61.8 \%$, $86.6 \%$ and $72 \%$ in ADA, ETA AND RTX patients respectively at 1 year of treatment. Therapeutic effectiveness was comparable with the response rates in published observational trials. Conclusion: Our data demonstrate daily clinical practice in management of RA. The pattern of prescription is in agreement with the ACR/EULAR recommendations for initiation of biologicals in the treatment of RA.

${ }^{*}$ Corresponding author.

How to cite this paper: Abdulaziz, S. and El-Deek, B. (2014) A Single Center Experience in Biological Therapy for the Treatment of Rheumatoid Arthritis in Saudi Arabia. Open Journal of Rheumatology and Autoimmune Diseases, 4, 199-206. 


\section{Keywords}

\section{Single Center, Rheumatoid Arthritis, Saudi Arabia, Biological DMARDS, Disease Activity, Biologics}

\section{Introduction}

The introduction of biological therapies has dramatically changed the armament of treatment of Rheumatoid arthritis (RA). Randomized placebo-controlled trials (RCT) on Infliximab (INF) [1]-[3], Etarnercept (ETA) [4][7], Adalimumab (ADA) [8]-[10], and rituximab (RTX) [11]-[13] have all shown to be very effective at improving the symptoms and signs of RA and at preventing structural joint damage and loss of function in diseasemodifying anti-rheumatic drug (DMARD)-resistant disease. Use of biological DMARDs has increased over the past 15 years and ACR/EULAR recommendations to advocate early use of biological agents following an insufficient response to initial non-biological DMARD therapy [14] [15]. The primary goal of RA treatment is remission or low disease activity [16]-[18]; in other words, the concept of "Treat to target" has been adopted to maximize long-term health-related quality of life through control of symptoms, prevention of structural damage, normalization of function, and social participation [19]. Therapies targeted to minimize disease activity lead to achievement of treatment goals.

The researchers conduct this study to examine the functionality of the available biological DMARDs treatments in Saudi Arabia, which are not far from implementing these therapies in pace with the international recommendations. Initially INF was first introduced in the national health formulary of Saudi Arabia in 2005 for the treatment of RA patients. Subsequently ADA was approved in 2008 by the Saudi Health Authorities with expanding the use of anti-TNF for other inflammatory disorders including ankylosing spondylitis and psoriatic arthritis. RTX was already presented in the national formulary for oncology patients and was later approved for the treatment of RA in 2008. ETA was registered in 2009. Biological DMARDs therapy is prescribed on the basis of current international and national recommendations. However, patients treated in daily clinical practice differ from those in clinical trials with strict inclusion criteria. Once the biological therapy is registered by the Saudi health authorities, there is no limitation in prescribing the medication by the rheumatologist to any Saudi citizen if needed in his management.

The objective of the study is to describe characteristics of Saudi RA patients at the initiation of biological DMARDs therapy and to evaluate clinical effectiveness of this therapy measured by DAS 28, in our rheumatology unit in King Fahad Hospital, Jeddah western Saudi Arabia which is a referral center from Jeddah as well as the surrounding small districts.

\section{Methods}

The study was approved by the local institutional review and ethical board committee and was conducted in a single tertiary center by collecting all cases on biological DMARDs therapy prescribed for RA through the hospital main pharmacy in King Fahd Hospital, Jeddah from 2005 till July 2011. It is a retrospective case series, in which the exclusion criteria are limited to the contraindications stated in the Summary of the Product characteristics (SPC) of each drug. Information was retrieved from the medical records of the patients by using a data sheet for RA patients on biological therapy regarding patient demographics and characteristics, including indications, disease duration, comorbidities, clinical, radiological and laboratory features. These are: (disease duration, extra-articular manifestations, tender and swollen joint counts, visual analog scale, erythrocyte sedimentation rate, rheumatoid factor (RF), anti-citrullinated peptide antibodies ACPA and evidence of erosions on hand XRay films). Previous DMARDS was checked, as well the number of disease modifying drugs used before start of biologicals. History of tuberculosis (TB) or previous exposure to contacts or family histories are documented, screening for latent TB are obtained and if positive, it is asked wither prophylactic treatment with isoniazide (INH) was given. Efficacy was assessed using DAS 28 [20] for RA. Baseline 0, 6, 12 months evaluation were recorded. Outcomes at 6 and 12 months were categorized according to the DAS scores. Based on the European League against Rheumatism (EULAR) Improvement Criteria [21], individual patients are classified into three groups: no response, moderate response and good response, based on their 6 month DAS 28 and absolute change 
in the DAS 28 from baseline. A good responder must demonstrate an improvement of at least 1.2 units and achieve an absolute score of $<3.2$. A non-responder should demonstrate an improvement of $<0.6$ or have a final DAS $28>5.1$. Moderate response falls in between. Patients achieved remission according to the EULAR criteria when the DAS $28<2.6$.

\section{Planned Statistical Analysis}

Data was analyzed using the statistical package of social science (SPSS-16) database program.

Descriptive statistics was done including number of observations, mean, minimum and maximum for continuous variables: count and percentages for categorical variables. Differences between the categorical variables were tested using the Pearson's Chi2 test and Yates correction was used when indicated. Differences between the continuous variables were tested using the one-way Annova (F test). A p-value $<0.05$ was considered significant.

\section{Results}

The baseline characteristics at the start of the biological therapy are presented in Table 1. One hundred and

Table 1. Baseline characteristics of rheumatoid patients on Adalimumab, Etarnercept, Infliximab, and Rituximab.

\begin{tabular}{|c|c|c|c|c|c|}
\hline & $\begin{array}{c}\text { TOTAL } \\
\text { n: } 139\end{array}$ & $\begin{array}{c}\text { ADALIMUMAB } \\
\text { n: } 45\end{array}$ & $\begin{array}{c}\text { ETARNERCEPT } \\
\text { n: } 35\end{array}$ & $\begin{array}{c}\text { INFLIXIMAB } \\
\text { n: } 6\end{array}$ & $\begin{array}{c}\text { RITUXIMAB } \\
\text { n: } 53\end{array}$ \\
\hline Age ( Years) \pm SD & $46 \pm 13$ & $45.9 \pm 12.2$ & $46.2 \pm 15.8$ & $50.4 \pm 5.4$ & $45.1 \pm 12.4$ \\
\hline Range & $(19-97)$ & $(22-72)$ & $(19-97)$ & $(45-58)$ & $(19-72)$ \\
\hline Females, n \% & 118 (84.9) & $42(91.3)$ & $32(91.4)$ & $3(6)$ & $41(77.4)$ \\
\hline Duration Mean (Years) & 7.24 & 5.9 & 6.4 & 11.2 & 8.4 \\
\hline Range (Years) & $(1-45)$ & $(0.8-23)$ & $(0.8-30)$ & $(0.5-18)$ & $(2-45)$ \\
\hline Disease $<1$ Year, no \% & $16(11.8)$ & $6(14)$ & $2(6)$ & - & $8(15.1)$ \\
\hline Disease $>1$ Year, no \% & $121(88.2)$ & $37(86)$ & $32(94)$ & $5(100 \%)$ & 45 (84.9) \\
\hline $\mathbf{R F}^{+}$ve, $\mathbf{n} \%$ & 88 (63.3) & 28 (60.9) & $22(62.9)$ & $4(80)$ & $34(66)$ \\
\hline $\mathrm{ACPA}^{+}$ve, $\mathbf{n} \%$ & $110(78.4)$ & $37(84.8)$ & $25(71.4)$ & $6(100)$ & $41(77.4)$ \\
\hline \multicolumn{6}{|l|}{ Chest X-Ray } \\
\hline Fibrosis (n \%) & $8(5.8)$ & 2 & 1 & 1 & 4 \\
\hline TB Exposure n (\%) & $11(8.4)$ & 4 & 2 & - & 5 \\
\hline PPD Test > 5 mm, n (\%) & $17(12.2)$ & 5 & 3 & - & 9 \\
\hline INH Prophylaxis n (\%) & $17(12.2)$ & 5 & 3 & - & 9 \\
\hline \multicolumn{6}{|l|}{ Cormorbidity n (\%) } \\
\hline No Cormorbid Illness & $29(24)$. & $6(20.7)$ & $9(31.0)$ & $1(3.4)$ & $13(44.8)$ \\
\hline 1 Cormorbid Illness & 41 (30.7) & $13(31.7)$ & 11 (26.8) & $2(4.9)$ & $15(36.6)$ \\
\hline$\geq 2$ Cormorbid Illness & $61(45.3)$ & $23(39.2)$ & $11(18)$ & $2(3.3)$ & $25(41)$ \\
\hline \multicolumn{6}{|l|}{ Nodules n (\%) } \\
\hline Baseline & $19(13.6)$ & 6 & 3 & 3 & 7 \\
\hline Durning Follow Up & 1 & 0 & 0 & 1 & 0 \\
\hline \multicolumn{6}{|l|}{ DMARDs n (\%) } \\
\hline 1 DMARD & $31(22 \%)$ & $14(30.4)$ & $4(11.4)$ & 0 & $13(24.5)$ \\
\hline$\geq 2$ DMARDs & $101(72 \%)$ & $29(61.0)$ & $27(77.1)$ & $6(100)$ & $40(80.5)$ \\
\hline Metrotrexate & $115(83 \%)$ & $34(73.3)$ & $31(88.6)$ & $6(100)$ & $45(84.9)$ \\
\hline Present Biologicals n (\%) & 139 & $45(32.2)$ & $35(25.2)$ & $6(4.3)$ & $53(38.1)$ \\
\hline Choice of 1st Biological n (\%) & 139 & $44(31.7)$ & $32(23)$ & $22(15.8)$ & $31(22.0)$ \\
\hline Choice of $2^{\text {nd }}$ Biological n (\%) & $33(45.87)$ & $5(16.5)$ & $4(13.2)$ & $1(3.3)$ & $23(75.9)$ \\
\hline
\end{tabular}

$\mathrm{RF}^{+}$: Rheumatoid factor positive; $\mathrm{ACPA}^{+}$: Anti-citrulinated peptide antibodies; TB: Tuberculosis; PPD: purified protein derivative; INH: Isoniazide; DMARDs: Disease modifying anti-rheumatic drugs. 
thirty nine patients were studied, (mean age $46 \pm 13$ years), ranging from 19 - 97 years of which 118 (84\%) were females; mean duration of the RA was $7.2 \pm 6.4$ years. Those that presented with disease duration $>1$ year were 121 (75.6\%) of RA patients. RF was positive in 88 patients (63.3\%) and ACPA was positive in 110 patients (78.4\%) of the patients. Lung fibrosis was present in 8 patients $(11.12 \%)$. One or more comorbidities were present in 102 patients (73.3\%). Rheumatoid nodules were present before the start of therapy with ADA 6 patients, ETA 3 patients, INF 3 patients, and RTX 7 patients. All had complete resolution of the nodules except for 1 patient on INF.

First choice of biological drug was ADA 44 patients (31.7\%), ETA 32 patients (23\%), IFA 22 patients (15.8\%), and RTX in 31 patients (22\%). RTX was the most frequently prescribed 2nd biological drug. Present biological treatment at the time of analysis was with ADA 45 patients (32.4\%), ETA 35 patients (25.2\%), INF 6 patients (4.3\%), and RTX 53 patients (38.1\%).

Mean DAS 28 activity at baseline was in ADA is 41 patients $(6.10 \pm 1.10)$, ETA 29 patients $(6.60 \pm 1.30)$, and RTX 50 patients $(6.7 \pm 1.32)$ as shown in Table 2. INF was excluded from final analysis due to the very small number of patients as well as missing data at follow-up. Mean DAS 28 activity at 6 months in patients on ADA 27 patients ( $3.69 \pm 1.52)$, ETA 21 patients (3.94 \pm 1.35 ) and RTX 35 patients $(4.63 \pm 2.01)$; Mean DAS 28 activity at 12 months on ADA 22 patients (4.36 \pm 1.72 ), ETA 15 patients ( $3.69 \pm 1.57$ ), and in RTX 25 patients $(4.03 \pm 1.69)$ with significant $\mathrm{p}<0.05$ was observed at 6 and 12 months in all the 3 drugs. Table 3 indicates that remission was obtained in 8 patients (29.6\%) and 4 (19.6\%) on ADA at 6 and 12 months respectively; 3 patients (14.3\%) and 5 patients (33.3\%) obtained remission on ETA at 6 and 12 months respectively. Patents on RTX achieved remission in 5 patients (14.3\%) and 4 patients (16\%) at 6 and 12 months respectively. Moderate to good EULAR response, as shown in Table 4, was obtained in (74\%), (85.7\%), and (53.3\%), at 6 months in

Table 2. Mean disease activity of RA patients on Adalimumab, Etarnercept and Rituximab at 0,6 and 12 months.

\begin{tabular}{|c|c|c|c|c|c|c|}
\hline DAS 28 & $\begin{array}{c}\text { Adalimumab } \\
\text { n (\%) }\end{array}$ & P-VALUE & $\begin{array}{c}\text { Etarnercept } \\
\text { n (\%) }\end{array}$ & P-VALUE & $\begin{array}{c}\text { Rituximab } \\
\text { n (\%) }\end{array}$ & P-VALUE \\
\hline 0 Months & $6.10 \pm 1.10$ & & $6.60 \pm 1.30$ & & $6.7 \pm 1.32$ & \\
\hline n: 120 & 41 & & 29 & & 50 & \\
\hline $\begin{array}{l}6 \text { Months } \\
\text { n: } 83\end{array}$ & $\begin{array}{c}3.69 \pm 1.52 \\
27\end{array}$ & $\mathrm{p}<0.001$ & $\begin{array}{c}3.94 \pm 1.35 \\
21\end{array}$ & $\mathrm{p}<0.001$ & $\begin{array}{c}4.63 \pm 2.01 \\
35\end{array}$ & $\mathrm{p}<0.001$ \\
\hline $\begin{array}{l}12 \text { Months } \\
\text { n: } 62\end{array}$ & $\begin{array}{c}4.36 \pm 1.72 \\
22\end{array}$ & $\mathrm{p}<0.001$ & $\begin{array}{c}3.69 \pm 1.57 \\
15\end{array}$ & $\mathrm{p}<0.001$ & $\begin{array}{c}4.03 \pm 1.6 \\
25\end{array}$ & $\mathrm{p}<0.001$ \\
\hline
\end{tabular}

Data presented as frequency (percentage) unless otherwise stated. DAS 28 = Disease activity score 28 joints. Paired t test was used to compare between serial measurements. Significant $\mathrm{p}<0.05$.

Table 3. EULAR disease activity in RA patients on Adalimumab, Etarnercept, and Rituximab at 0, 6 and 12 months.

\begin{tabular}{|c|c|c|c|}
\hline EULAR disease activity & $\begin{array}{c}\text { Adalimumab } \\
\text { n (\%) }\end{array}$ & $\begin{array}{c}\text { Etarnercept } \\
\text { n (\%) }\end{array}$ & $\begin{array}{c}\text { Rituximab } \\
\text { n (\%) }\end{array}$ \\
\hline 0 Months n \% & & & 50 \\
\hline HDA > 5.1 & 41 & 29 & $44(88)$ \\
\hline MDA $>3.2<5.1$ & 34 (82.9) & 23 (79.3) & $\begin{array}{l}44(88) \\
5(10)\end{array}$ \\
\hline LDA $>2.6<3.2$ & $7(17.1)$ & $6(20.7)$ & $5(10)$ \\
\hline \multicolumn{4}{|l|}{ Remission $<2.6$} \\
\hline 6 Months n \% & 27 & 21 & 35 \\
\hline HDA $>5.1$ & 7 (25.9) & $3(14.3)$ & $16(45.7)$ \\
\hline MDA $>3.2<5.1$ & $7(25.9)$ & $8(38.1)$ & $11(31.4)$ \\
\hline LDA $>2.6<3.2$ & $5(18.5)$ & 7 (33.3) & $3(8.6)$ \\
\hline Remission $<2.6$ & $8(29.6)$ & $3(14.3)$ & 5 (14.3) \\
\hline 12 Months n\% & 21 & 15 & 25 \\
\hline HDA $>5.1$ & $8(38.1)$ & 2 (13.3\%) & 7 (28) \\
\hline MDA $>3.2<5.1$ & 7 (33.3) & $6(40 \%)$ & $9(36)$ \\
\hline LDA $>2.6<3.2$ & $2(9.5)$ & $2(13.3 \%)$ & $5(20)$ \\
\hline Remission $<2.6$ & $4(19)$ & $5(33.3 \%)$ & $4(16)$ \\
\hline
\end{tabular}

Data presented as frequency (percentage) unless otherwise stated. HAD = High disease activity; MDA = Moderate disease activity; LDA = Low disease activity. 
Table 4. EULAR disease activity response in patients on Adalimumab, Etarnercept, and Rituximab.

\begin{tabular}{|c|c|c|c|}
\hline & $\begin{array}{c}\text { Adalimumab } \\
\mathrm{n}(\%)\end{array}$ & $\begin{array}{c}\text { Etarnercept } \\
\mathrm{n}(\%)\end{array}$ & $\begin{array}{c}\text { Rituximab } \\
\text { n (\%) }\end{array}$ \\
\hline 6 Months & & & \\
\hline $\begin{array}{l}\text { Good EULAR Response } \\
\text { DAS } 28 \leq 3.2\end{array}$ & $13(48.1)$ & $10(47.6)$ & 8 (22.9) \\
\hline $\begin{array}{l}\text { Moderate EULAR Response } \\
\text { DAS } 28>3.2 \text { and } \leq 5.1\end{array}$ & 7 (25.9) & $8(38.1)$ & $11(31.4)$ \\
\hline $\begin{array}{l}\text { No EULAR Response } \\
\text { DAS } 28>5.1\end{array}$ & 7 (25.9) & $3(14.3)$ & $16(45.7)$ \\
\hline $\begin{array}{l}12 \text { Months } \\
\text { Good EULAR Response } \\
\text { DAS } 28 \leq 3.2\end{array}$ & $6(28.5)$ & $7(46.6)$ & $9(36.0)$ \\
\hline $\begin{array}{l}\text { Moderate EULAR Response } \\
\text { DAS } 28>3.2 \text { and } \leq 5.1\end{array}$ & 7 (33.3) & $6(40.0)$ & $9(36.0)$ \\
\hline $\begin{array}{l}\text { No EULAR Response } \\
\text { DAS } 28>5.1\end{array}$ & $8(38.1)$ & $2(13.3)$ & $7(28.0)$ \\
\hline
\end{tabular}

Data presented as frequency (percentage) unless otherwise stated. DAS 28: Disease activity score 28 joint.

ADA, ETA and RTX patients respectively. Moderate to good EULAR response was obtained in $61.8 \%$, 86.6\% and $72 \%$ in ADA, ETA, and RTX patients respectively at 1year of treatment. Therapeutic effectiveness was comparable with the response rates in published observational trials.

\section{Discussion}

Our study describes the practice of a single rheumatology center King Fahad Hospital in prescribing biological DMARDs therapy in the management of RA. To our knowledge, this is the first single center cohort addressing initiation and effectiveness of biologically treated RA patients in Saudi Arabia. Real life observational cohort studies add imperative knowledge to data derived from RCTs with their strict inclusions criteria.

The demographic characteristics of the patients were comparable across the cohorts in the other observational studies as in GLADER, DREAM and DANBIO registries [22]-[24]. Our patients had long standing disease with a mean 7.2 ranging from 1 - 45 years with failure of two or more DMARDs and the mean DAS 28 score 6.82 ( \pm 1.38 ) in implementation of the EULAR/ACR guidelines for the initiation of biological therapy. Only $12 \%$ of our patients had disease duration of less than one year reflecting the importance of early referral and early disease control. The first choice of biological therapy was ADA and the second choice biological therapy after the failure of the first was RTX, which is consistent with the ACR/EULAR recommendations [14] [15] [23]. The choice of biological agent was strongly associated with the preferences of the individual doctors, the year of treatment initiation, and availability of the drug in the hospital. Therefore, INF was the first in 2005, ADA and RTX in 2008, and ETA was in 2009.

In our cohort of RA patients the DAS 28 at 6 months and 12 months for patients on ADA was $3.7 \pm 1.5$ and $4.4 \pm 1.72$ respectively with a significant p-value $<0.001$. Moderate to good EULAR responses. DAS $28 \leq 3.2$ was obtained in $75 \%$ and $62 \%$ at 6 months and 12 months [10]. This is in contrast to the DANBIO registry which showed a slight increase in good to moderate EULAR response in $85 \%$ and $86 \%$ at 6 and 12 months [24]. A slight increase of DAS 28 activity was seen at 12 months in our cohort which could be explained with the periods of drug unavailability especially the end of each year when a new drug is introduced in a governmental institute.

The RA patients on ETA, the mean DAS 28 activity at 6 months and 12 months was $3.9 \pm 1.35$ and $3.69 \pm$ 1.57 respectively with a significant $\mathrm{p}<0.001$. Good and moderate EULAR response was seen in $85 \%$ and $86 \%$ at 6 months and 12 months as was seen in others studies as in the Hellenic registry [25], by Kievit et al. [26] and by Zink and his colleagues [27]. Only 44\% of the ETA group had comorbid illnesses.

Patients in the RTX had a long duration of disease 8.4 years with one or more comorbidities in $77.6 \%$ and use of two or more DMARDS in $80 \%$ and failure of previous anti-TNF therapy. It was the most commonly used 2nd 
choice of biological DMARDs therapy in RA patients. In 22\% of all the RA patients on biological DMARDs RTX was used as the first line drug in those patients who refused anti-TNF or because of contraindications such as prior malignancy, presence of connective tissue disease, previous tuberculosis or those patients from remote areas surrounding Jeddah having problems with compliance with subcutaneous therapy. According to the EULAR response criteria, 53.3\% of the patients on RTX achieved good to moderate response at 6 months in agreement with results from the observational study by Moetaza et al. [28] However the response in a randomized REFLEX trial [12] was slightly higher (65\%) due to strict inclusion criteria used in clinical trials omitting non trivial comorbidities. IFX was the first drug available in our center since 2005 as the first choice of biological DMARDs but once the subcutaneous biological therapy were available it was reserved for other CTD due to limited beds in the day care unit. INF was excluded from the final analysis due to the small number and due to the large amount of missing data. Our study has some limitations given the retrospective nature of the study. Though IFX was started early as 2005, composite measures were not used initially for the assessment for response to therapy.

\section{Conclusion}

The data presented in this study present "real world patients" and realistic clinical practice. The results from this retrospective study indicate our practice is in consistence of the ACR/EULAR guidelines in the initiation of biological therapy. The actual response observed in our cohort was slightly lower than the results obtained in randomized controlled trials but consistent with published observational cohort studies describing daily practice. With the widening of the paradigm of management of RA, national registries are of great importance with a major advantage over industry-driven observational post-marketing studies for long-term evaluation of safety and effectiveness of the new generation of biological therapy.

\section{Acknowledgements}

The authors express their sincere appreciation and gratitude to Dr. Hani Almoallim for his critical review as well as to Dr. Khatijah Bawazeer for her editorial assistance. The authors thank Dr. Maysoon Taher, consultant rheumatologist in managing the rheumatoid patients and Dr. Nadia Alharbi in helping in the data collection.

\section{Funding}

None.

\section{Disclosures}

The authors declare no conflicts of interest.

\section{References}

[1] Maini, R., St. Clair, E.W., Breedveld, F., Furst, D., Kalden, J., Weisman, M., et al. (1999) Infliximab (Chimeric Anti-Tumour Necrosis Factor Alpha Monoclonal Antibody) versus Placebo in Rheumatoid Arthritis Patients Receiving Concomitant Methotrexate: A Randomised Phase III Trial. Attract Study Group. Lancet, 354, 1932-1939. http://dx.doi.org/10.1016/S0140-6736(99)05246-0

[2] Lipsky, P.E., van der Heijde, D.M., St. Clair, E.W., Furst, D.E., Breedveld, F.C., Kalden, J.R., et al. (2000) Infliximab and Methotrexate in the Treatment of Rheumatoid Arthritis. The New England Journal of Medicine, 343, 1594-1602. http://dx.doi.org/10.1056/NEJM200011303432202

[3] Kavanaugh, A., St. Clair, E.W., McCune, W.J., Braakman, T. and Lipsky, P. (2000) Chimeric Anti-Tumor Necrosis Factor-Alpha Monoclonal Antibody Treatment of Patients with Rheumatoid Arthritis Receiving Methotrexate Therapy. The Journal of rheumatology, 27, 841-850.

[4] Moreland, L.W., Schiff, M.H., Baumgartner, S.W., Tindall, E.A., Fleischmann, R.M., Bulpitt, K.J., et al. (1999) Etarnercept Therapy in Rheumatoid Arthritis: A Randomized, Controlled Trial. Annals of Internal Medicine, 130, 478-486. http://dx.doi.org/10.7326/0003-4819-130-6-199903160-00004

[5] Weinblatt, M.E., Schiff, M.H., Ruderman, E.M., Bingham, C.O., Li, J., Louie, J. and Furst, D.E. (2008) Efficacy and Safety of Etanercept $50 \mathrm{mg}$ Twice a Week in Patients with Rheumatoid Arthritis Who Had a Suboptimal Response to Etanercept 50 mg Once a Week: Results of a Multicenter, Randomized, Double-Blind, Active Drug-Controlled Study. 
Arthritis and rheumatism, 58, 1921-1930. http://dx.doi.org/10.1002/art.23493

[6] Keystone, E.C., Schiff, M.H., Kremer, J.M., Kafka, S., Lovy, M., DeVries, T., et al. (2004) Once-Weekly Administration of $50 \mathrm{mg}$ Etanercept in Patients with Active Rheumatoid Arthritis: Results of a Multicenter, Randomized, DoubleBlind, Placebo-Controlled Trial. Arthritis and rheumatism, 50, 353-363. http://dx.doi.org/10.1002/art.20019

[7] van der Heijde, D., Klareskog, L., Rodriguez-Valverde, V., Codreanu, C., Bolosiu, H., Melo-Gomes, J., et al. (2006) Comparison of Etarnercept and Methotrexate, Alone and Combined, in the Treatment of Rheumatoid Arthritis: Two-Year Clinical and Radiographic Results from the TEMPO Study, a Double-Blind, Randomized Trial. Arthritis and Rheumatism, 54, 1063-1074. http://dx.doi.org/10.1002/art.21655

[8] Weinblatt, M.E., Keystone, E.C., Furst, D.E., Kavanaugh, A.F., Chartash, E.K. and Segurado, O.G. (2006) Long Term Efficacy and Safety of Adalimumab plus Methotrexate in Patients with Rheumatoid Arthritis: ARMADA 4 Year Extended Study. Annals of the Rheumatic Diseases, 65, 753-759. http://dx.doi.org/10.1136/ard.2005.044404

[9] van de Putte, L.B., Atkins, C., Malaise, M., Sany, J., Russell, A.S., van Riel, P.L., et al. (2004) Efficacy and Safety of Adalimumab as Monotherapy in Patients with Rheumatoid Arthritis for Whom Previous Disease Modifying Antirheumatic Drug Treatment Has Failed. Annals of the Rheumatic Diseases, 63, 508-516. http://dx.doi.org/10.1136/ard.2003.013052

[10] Keystone, E.C., Kavanaugh, A.F., Sharp, J.T., Tannenbaum, H., Hua, Y., Teoh, L.S., et al. (2004) Radiographic, Clinical, and Functional Outcomes of Treatment with Adalimumab (a Human Anti-Tumor Necrosis Factor Monoclonal Antibody) in Patients with Active Rheumatoid Arthritis Receiving Concomitant Methotrexate Therapy: A Randomized, Placebo-Controlled, 52-Week Trial. Arthritis and rheumatism, 50, 1400-1411. http://dx.doi.org/10.1002/art.20217

[11] Emery, P., Fleischmann, R., Filipowicz-Sosnowska, A., Schechtman, J., Szczepanski, L., Kavanaugh, A., et al. (2006) The Efficacy and Safety of Rituximab in Patients with Active Rheumatoid Arthritis despite Methotrexate Treatment: Results of a Phase IIB Randomized, Double-Blind, Placebo-Controlled, Dose-Ranging Trial. Arthritis and Rheumatism, 54, 1390-1400. http://dx.doi.org/10.1002/art.21778

[12] Keystone, E.C., Cohen, S.B., Emery, P., Kremer, J.M., Dougados, M., Loveless, J.E., et al. (2012) Multiple Courses of Rituximab Produce Sustained Clinical and Radiographic Efficacy and Safety in Patients with Rheumatoid Arthritis and an Inadequate Response to 1 or More Tumor Necrosis Factor Inhibitors: 5-Year Data from the REFLEX Study. The Journal of Rheumatology, 39, 2238-2246. http://dx.doi.org/10.3899/jrheum.120573

[13] Smolen, J.S., Keystone, E.C., Emery, P., Breedveld, F.C., Betteridge, N., Burmester, G.R., et al., The Working Group on the Rituximab Consensus Statement (2007) Consensus Statement on the Use of Rituximab in Patients with Rheumatoid Arthritis. Annals of the Rheumatic Diseases, 66, 143-150. http://dx.doi.org/10.1136/ard.2006.061002

[14] Singh, J.A., Furst, D.E., Bharat, A., Curtis, J.R., Kavanaugh, A.F., Kremer, J.M., et al. (2012) 2012 Update of the 2008 American College of Rheumatology Recommendations for the Use of Disease-Modifying Antirheumatic Drugs and Biologic Agents in the Treatment of Rheumatoid Arthritis. Arthritis Care \& Research, 64, 625-639. http://dx.doi.org/10.1002/acr.21641

[15] Smolen, J.S., Landewe, R., Breedveld, F.C., Dougados, M., Emery, P., Gaujoux-Viala, C., et al. (2010) EULAR Recommendations for the Management of Rheumatoid Arthritis with Synthetic and Biological Disease-Modifying Antirheumatic Drugs. Annals of the Rheumatic Diseases, 69, 964-975. http://dx.doi.org/10.1136/ard.2009.126532

[16] Bathon, J.M. and Cohen, S.B. (2008) The 2008 American College of Rheumatology Recommendations for the Use of Nonbiologic and Biologic Disease-Modifying Antirheumatic Drugs in Rheumatoid Arthritis: Where the Rubber Meets the Road. Arthritis and Rheumatism, 59, 757-759. http://dx.doi.org/10.1002/art.23723

[17] Aletaha, D., Ward, M.M., Machold, K.P., Nell, V.P., Stamm, T. and Smolen, J.S. (2005) Remission and Active Disease in Rheumatoid Arthritis: Defining Criteria for Disease Activity States. Arthritis and Rheumatism, 52, 2625-2636. http://dx.doi.org/10.1002/art.21235

[18] Aletaha, D., Funovits, J., Keystone, E.C. and Smolen, J.S. (2007) Disease Activity Early in the Course of Treatment Predicts Response to Therapy after One Year in Rheumatoid Arthritis Patients. Arthritis and Rheumatism, 56, 32263235. http://dx.doi.org/10.1002/art.22943

[19] Haraoui, B., Smolen, J.S., Aletaha, D., Breedveld, F.C., Burmester, G., Codreanu, C., et al., the Treat to Target Taskforce (2011) Treating Rheumatoid Arthritis to Target: Multinational Recommendations Assessment Questionnaire. Annals of the Rheumatic Diseases, 70, 1999-2002. http://dx.doi.org/10.1136/ard.2011.154179

[20] Prevoo, M.L., van’t Hof, M.A., Kuper, H.H., van Leeuwen, M.A., van de Putte, L.B. and van Riel, P.L. (1995) Modified Disease Activity Scores That Include Twenty-Eight-Joint Counts. Development and Validation in a Prospective Longitudinal Study of Patients with Rheumatoid Arthritis. Arthritis and Rheumatism, 38, 44-48. http://dx.doi.org/10.1002/art.1780380107

[21] van Gestel, A.M., Prevoo, M.L., van’t Hof, M.A., van Rijswijk, M.H., van de Putte, L.B. and van Riel, P.L. (1996) Development and Validation of the European League against Rheumatism Response Criteria for Rheumatoid Arthritis. Comparison with the Preliminary American College of Rheumatology and the World Health Organization/International 
League against Rheumatism Criteria. Arthritis and Rheumatism, 39, 34-40. http://dx.doi.org/10.1002/art.1780390105

[22] Cardiel, M.H., Pons-Estel, B.A., Sacnun, M.P., Wojdyla, D., Saurit, V., Marcos, J.C., et al. (2012) Treatment of Early Rheumatoid Arthritis in a Multinational Inception Cohort of Latin American Patients: The GLADAR Experience. Journal of Clinical Rheumatology, 18, 327-335. http://dx.doi.org/10.1097/RHU.0b013e31826d6610

[23] Soliman, M.M., Hyrich, K.L., Lunt, M., Watson, K.D., Symmons, D.P., Ashcroft, D.M., on Behalf of the British Society for Rheumatology Biologics Register (2012) Rituximab or a Second Anti-Tumor Necrosis Factor Therapy for Rheumatoid Arthritis Patients Who Have Failed Their First Anti-Tumor Necrosis Factor Therapy? Comparative Analysis from the British Society for Rheumatology Biologics Register. Arthritis Care \& Research, 64, 1108-1115. http://dx.doi.org/10.1002/acr.21663

[24] Hetland, M.L., Christensen, I.J., Tarp, U., Dreyer, L., Hansen, A., Hansen, I.T., et al. (2010) Direct Comparison of Treatment Responses, Remission Rates and Drug Adherence in Patients with Rheumatoid Arthritis Treated with Adalimumab, Etanercept or Infliximab: Results from Eight Years of Surveillance of Clinical Practice in the Nationwide Danish DANBIO Registry. Arthritis and Rheumatism, 62, 22-32. http://dx.doi.org/10.1002/art.27227

[25] Flouri, I., Markatseli, T.E., Voulgari, P.V., Boki, K.A., Papadopoulos, I., Settas, L., et al. (2014) Comparative Effectiveness and Survival of Infliximab, Adalimumab and Etanercept for Rheumatoid Arthritis Patients in the Hellenic Registry of Biologics: Low Rates of Remission and 5-Year Drug Survival. Seminars in Arthritis and Rheumatism, 43, 447-457. http://dx.doi.org/10.1016/j.semarthrit.2013.07.011

[26] Kievit, W., Fransen, J., Oerlemans, A.J., Kuper, H.H., van der Laar, M.A., de Rooij, D.J., et al. (2007) The Efficacy of Anti-TNF in Rheumatoid Arthritis, a Comparison between Randomised Controlled Trials and Clinical Practice. Annals of the Rheumatic Diseases, 66, 1473-1478. http://dx.doi.org/10.1136/ard.2007.072447

[27] Zink, A., Strangfeld, A., Schneider, M., Herzer, P., Hierse, F., Stoyanova-Scholz, M., et al. (2006) Effectiveness of Tumor Necrosis Factor Inhibitors in Rheumatoid Arthritis in an Observational Cohort Study: Comparison of Patients According to Their Eligibility for Major Randomized Clinical Trials. Arthritis and Rheumatism, 54, 3399-3407. http://dx.doi.org/10.1002/art.22193

[28] Soliman, M.M., Hyrich, K.L., Lunt, M., Watson, K.D., Symmons, D.P., Ashcroft, D.M., the British Society for Rheumatology Biologics Register (2012) Effectiveness of Rituximab in Patients with Rheumatoid Arthritis: Observational Study from the British Society for Rheumatology Biologics Register. The Journal of Rheumatology, 39, $240-246$. http://dx.doi.org/10.3899/jrheum.110610 
Scientific Research Publishing (SCIRP) is one of the largest Open Access journal publishers. It is currently publishing more than 200 open access, online, peer-reviewed journals covering a wide range of academic disciplines. SCIRP serves the worldwide academic communities and contributes to the progress and application of science with its publication.

Other selected journals from SCIRP are listed as below. Submit your manuscript to us via either submit@scirp.org or Online Submission Portal.
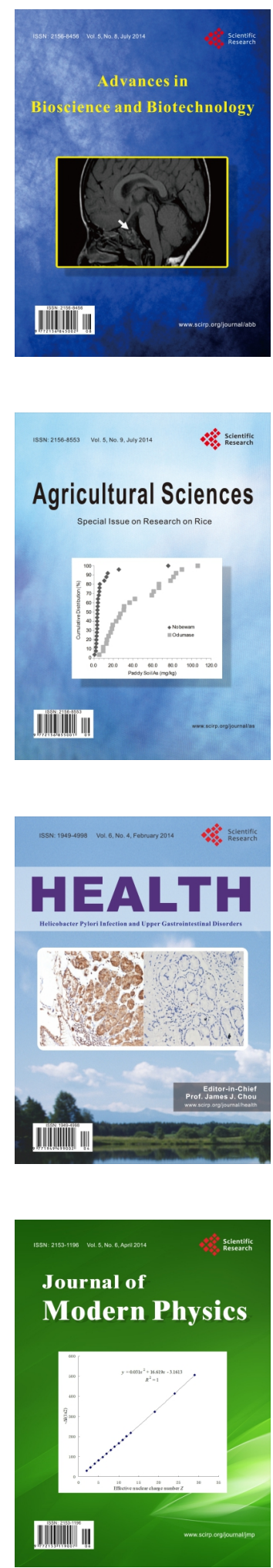
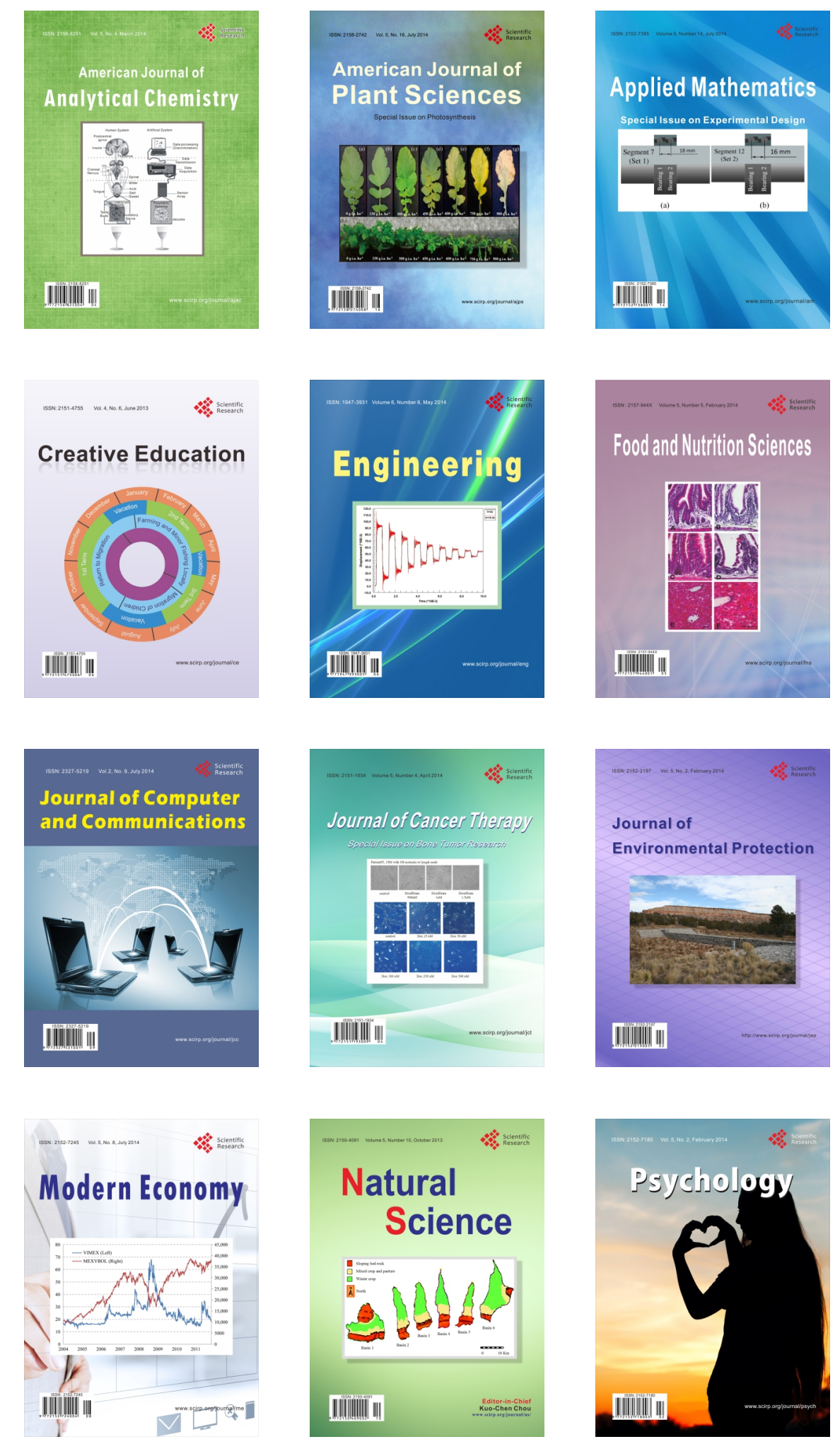